CERN discloses plans for new accelerator

LEP, a particle accelerator to collide 22-130 GeV electrons with their antiparticles, positrons, at the same energy, would begin construction near Geneva in early 1982 if plans announced at last week's CERN Council meeting are accepted. John Adams, Director-General of the Centre for european nuclear physics (CERN), said that he planned to submit a firm proposal for LEP to the Council the supreme body of CERN on which all member states are represented - in June 1980. A decision could be taken in June 1981.

LEP would probably be $5 \mathrm{~km}$ in radius, and be built underground. It could be built without increasing the present CERN budget of 593 million Sw Fr per year, and no new staff would be needed, said Adams; but the intersecting storage rings (for proton-proton collisions) would be phased out, and the old $8 \mathrm{GeV}$ synchrocyclotron CERN's first machine - reduced to serve only the low energy physics 'Isotope separator on line' (ISOLDE), which is widely used by Scandinavian members of CERN and has produced much useful data on short-lived isotopes.

\section{USSR to license use of advanced energy technologies}

THE Soviet Union will license the use of 30 processes for eliminating the high sulphur content of coal and for developing electricity production through magnetohydrodynamics to the US. The agreement signed by the USSR foreign trade organisation Licensintorg and the US firm Control Data Corporation, is a consequence of a deal made several years ago when Control Data supplied a superconducting magnet to the USSR for use in MHD experiments. In return, Control Data saved the need to build a MHD test plant of its own.

\section{US to stop funding labour-} saving agriculture research

THE US Secretary of Agriculture Mr Bob Bergland, has announced that federal research funds distributed to land-grant colleges and universities can no longer be used to support research into the mechanisation of agricultural processes leading to reduced employment for farm workers.

Such research has come under increasing criticism in recent years for contributing to unemployment among farmworkers, particularly among migrant workers who had previously been dependent on seasonal agricultural work for a major proportion of their income. Critics charge that the federal research funds which are distributed to land-grant colleges on a prorata basis under the terms of the Hatch Act are merely serving to enrich large foodproducing corporations.

However, Secretary Bergland's move was criticised by Dr Charles E Hess, head of the College of Agricultural and Environmental Science at the University of California, Davis, who said that "to suggest halting research which significantly contributes to enhancing agricultural productivity and efficiency is irrational and irresponsible."

\section{France and China sign agreement on geological research}

AFTER eight days of meetings and visits to Chinese laboratories, Pierre Aigrain, the French Secretary of State for Research, signed an agreement on 14 December with Deng Xiao-ping, the Chinese vicePremier, to provide for Franco-Chinese cooperation in geological research. The agreement gives the go-ahead to three French missions to study the north slope of the Himalayas in 1981, 1982, and 1983. In return France will provide laboratory equipment for Chinese geological research. Other areas of possible cooperation are teacher exchanges, the evaluation by French specialists of Chinese mineral reserves, particularly chromium, and the establishment of a Chinese geological information bank. Mr Deng Xiao-ping called the agreement a step in the direction of correcting the "loss of scientific talent due to the Cultural Revolution'.

\section{Ariane makes it to the top}

ARIANE, Europe's - but mostly France's - very own space launcher, went aloft on Christmas Eve (24 December) only $2 \mathrm{~km}$ away from its planned trajectory. A few days after the launch, measurements showed that the payload - a small test satellite - was in an orbit with perigee (closest approach to Earth) of $202.6 \mathrm{~km}$, apogee (furthest distance) $36,019 \mathrm{~km}$, with an inclination of the plane of the orbit to the equator of $17^{\circ}$.

The launch appeared to demonstrate that the hitches which caused the abandonment of two launch attempts within a week were indeed minor. They are attributed to small instrumentation malfunctions.

The greatest achievement - and surprise - of the launch was the perfect operation of the hydrogen-burning third stage, which had not yet passed its ground qualification tests.

European Space Agency press announcements before the launch had hedged around what would be considered a 'successful' launch, urging journalists to count mere ignition of the third stage a 'success'. There will be three more trials in 1980; one more 'success' will be considered a 'qualification' of Ariane for its first commercial launches in 1981.

\section{GMAG invites proposals for scale-up}

THE UK Genetic Manipulation Advisory Group has issued guidelines for work with recombinant DNA "involving volumes of 10 litres or more". All proposals for "'scale up" will be judged on the basis of a site visit as such will be considered case by case rather than by a set of strict rules. GMAG will examine the biological aspects of proposals for "suitable levels of disablement and containment"'.

Physical plant will also have to be examined for pressure safety, leaks or cracking and safety and emergency procedures will be inspected as will sterilisation provisions for waste products. A GMAG official said that the requirements are not beyond industry's present procedures for biological manufacture as for example in vaccine and antibiotic productions. "We want to encourage not discourage applications. Industrial procedures are usually much safer than laboratory work and if the proposals are consistent with safety we would be quite happy".

\section{Saccharin confirmed as weak human carcinogen}

STUDIES carried out by the US National Cancer Institute have shown that heavy users of artificial sweeteners, especially those who consume diet drinks and other sugar substitutes, have a $60 \%$ increased risk of bladder cancer.

The study was based on interviews with more than 3000 bladder cancer patients and 6000 healthy people. It revealed "no increased risk" in the overall population being studied, but that those who used six or more servings a day of the sugar substitute saccharin, or two or more eightounce diet drinks, increased the risk of bladder cancer by $60 \%$.

Following announcement of the results of the study, the Food and Drug Administration, whose attempt to ban the use of saccharin has been blocked by Congress, announced that it confirmed its previous contentions that artificial sweeteners posed a cancer risk to humans. Dr Jere E Goyan, Commissioner of the FDA, said that the study was consistent which previous animal studies and scientist's conclusions that saccharin is a "weak carcinogen", in particular acting in conjunction with other causes of cancer, such as cigarette smoking. 